\title{
Aleksander Kacprzak
}

Uniwersytet Adama Mickiewicza w Poznaniu, Wydział Neofilologii ORCID: 0000-0002-2961-8221 | e-mail: aleksander.kacprzak@amu.edu.pl

\section{Afryka oczyma świata zachodniego - językowy stereotyp Afryki i jej mieszkańców w języku duńskim}

DOI: $10.34739 / \mathrm{clg} .2021 .13 .03$

\section{Wprowadzenie}

Prawdopodobnie trudno na świecie o równie piękny i kulturowo zróżnicowany kontynent jak Afryka. Etnolingwista odnajdzie w niej dom dla około 2000 różnych języków i, co za tym idzie, obrazów świata, historyk kolebkę jednych z najstarszych cywilizacji, a przyrodnik zachwycające bogactwo natury. Tymczasem, przy przeglądaniu stron poświęconych sprawom międzynarodowym w duńskich gazetach, trudno oprzeć się wrażeniu, że niezależnie od kontekstu sytuacyjnego Afryka jest w nich oddawana bardzo stereotypowo i jednostronnie. W świetle powyższych uwag warto się więc zastanowić, jak głęboko zakorzenione jest omawiane przez nas zjawisko i czy w języku duńskim funkcjonuje określony stereotyp Afryki, który mógłby potem rzutować na poglądy Duńczyków w pojedynczych zagadnieniach dotyczących tego kontynentu i znajdujących się na nim państw.

\section{Materiał i podstawa teoretyczna}

Jak można wywnioskować z uwag poczynionych we wstępie artykułu, nawiązując do podziału na Weltanschauung (światopogląd) i Weltansichten (obraz świata) (Underhill 2009: 55), niniejsze badanie skupia się zdecydowanie na odkrywaniu tego drugiego, rozumianego w następujący sposób:

Przyjmuję, że najogólniej mówiąc, jest zawartą w języku, zwerbalizowaną interpretacją rzeczywistości, dającą się ująć w postaci sądów o świecie. Mogą być to sądy "utrwalone”, czyli mające oparcie w samej materii języka, 
a więc $\mathrm{w}$ gramatyce, słownictwie, $\mathrm{w}$ kliszowanych tekstach (np. w przysłowiach), ale także sądy presuponowane, tj. implikowane przez formy językowe, utrwalone na poziomie społecznej wiedzy, przekonań, mitów i rytuałów (Bartmiński 2012: 12).

Tak rozumiany obraz świata jest natomiast nieodłącznie związany z racjonalnością potoczną, „stereotypem językowym”, w odróżnieniu od wiedzy eksperckiej bądź samej ekstensji wyrazu (Bartmiński 2007, 2012: 20; Putnam 2013: 141-153; szerzej Tokarski 2014: 80-88).

Celem artykułu jest odkrycie najbardziej spetryfikowanego językowo obrazu Afryki w oparciu o dane systemowe języka duńskiego czerpane z duńskich słowników oraz z korpusu języka duńskiego. Pierwsza część informacji, czyli derywaty i złożenia, pochodzić będzie z najbardziej obszernego i aktualnego słownika języka duńskiego, czyli Den Danske Ordbog (w skrócie DDO), który jest dostępny również w wersji online, aktualizowanej na bieżąco. Jeśli chodzi o definicje leksykalnych wykładników konceptu, od których zwykle rozpoczyna się analizy dotyczące językowego obrazu świata, DDO nie podaje definicji wyrazu Afrika i dlatego należy przyjąć tu inny punkt wyjścia - najlepszym rozwiązaniem wydaje się w tym wypadku sięgnięcie po encyklopedię Den Store Danske, dostępną również online ${ }^{1}$. Źródłem występujących w artykule wyrażeń bliskoznacznych będzie natomiast Den Danske Begrebsordbog (w skrócie DDB), który grupuje wyrazy i wyrażenia języka duńskiego wokół określonych pojęć, co pozwala na przeglądanie całych pól leksykalnosemantycznych. W końcu, dane korpusowe czerpane będą z internetowego korpusu języka duńskiego „Korpus DK”, obejmującego zróżnicowane gatunkowo teksty z lat około 1990 i 2000.

\section{Badanie}

Przeprowadzone badanie zostanie zaprezentowane w niniejszym artykule w trzech częściach - najpierw omówiona zostanie definicja pojęcia, następnie złożenia, derywaty i wyrazy bliskoznaczne, a na koniec wyniki analizy najbardziej utrwalonych połączeń wyrazowych obecnych w korpusie.

\subsection{Definicja pojęcia}

Encyklopedia Den Store Danske podaje następującą definicję pojęcia Afrika:

\footnotetext{
1 Pod adresem https://denstoredanske.lex.dk/.
} 
Afrika, jordens næststørste kontinent; 30 mio. km², over 1 mia. indb. (2010). Verdensdelen er omgivet af Atlanterhavet, Det Indiske Ocean og Middelhavet; afgrænses mod Asien af Det Røde Hav og Suezkanalen. Til verdensdelen hører også de nærliggende øer, bl.a. De Kanariske Øer, Kap Verde, Madagaskar, Mauritius, Réunion og Seychellerne.

Afrika er præget af fattigdom; først slavehandelen og siden kolonitiden medførte en alvorlig underudvikling af verdensdelen. I anden halvdel af 1900-t. er næsten alle de afrikanske lande blevet selvstændige, men mange præges fortsat af store problemer, blandt andet politisk uro. Den store Saharaørken adskiller det egentlige Afrika "det sorte Afrika" fra Nordafrika, som historisk, politisk og kulturelt hører til Middelhavsregionen og Mellemøsten. Navnet Africa var oprindelig betegnelsen for den romerske provins $i$ det daværende Kartagoområde. (Den Store Danske: https://denstoredanske.lex.dk/Afrika, dostęp: 2 XII 2021).

[Afryka to drugi największy kontynent na świecie, $30 \mathrm{mln} \mathrm{km}^{2}$, ponad 1 mld mieszkańców (w 2010). Ta część świata jest otoczona przez Ocean Atlantycki i Indyjski, a także przez Morze Śródziemne, od Azji dzieli ją natomiast Morze Czerwone i Kanał Sueski. Należą do niej leżące w pobliżu wyspy, między innymi Wyspy Kanaryjskie, Wyspy Zielonego Przylądka, Madagaskar, Mauritius, Réunion oraz Seszele.

Afryka charakteryzuje się biedą, najpierw handel niewolnikami a potem era kolonialna sprawiły, że ta część świata jest bardzo słabo rozwinięta. W drugiej połowie XX w. prawie wszystkie kraje afrykańskie zyskały niepodległość, ale wiele z nich wciąż nękana jest problemami, między innymi politycznym brakiem stabilizacji. Sahara jest linią podziału Afryki na „Czarną Afrykę” i Afrykę Północną, która z historycznego, politycznego i kulturowego punktu widzenia przynależy do regionu Morza Śródziemnego i Bliskiego Wschodu. Termin Afryka służył oryginalnie do określania rzymskiej prowincji znajdującej się w okolicach niegdysiejszej Kartaginy] ${ }^{2}$.

Choć należy pamiętać, że mamy tu do czynienia z definicją encyklopedyczną, a nie słownikową, wydaje się, że wciąż możemy na jej podstawie sformułować pewne początkowe obserwacje. W podanej powyżej wstępnej części hasła, (temat jest potem jeszcze rozwijany pod kilkunastoma deskryptorami, takimi jak ludność, geografia czy sztuka), znajduje się bowiem to, co według jego autorów stanowi najważniejsze i najbardziej charakterystyczne

\footnotetext{
2 Wszystkie tłumaczenia na język polski znajdujące się w niniejszym artykule wykonane zostały przez autora.
} 
informacje o Afryce. Z nich, oprócz oczywistych faktów dotyczących wielkości kontynentu i jego usytuowania względem innych części świata, dowiadujemy się że Afryka:

- jest naznaczona biedą;

- jest słabo rozwinięta;

- jest doświadczona przez handel niewolnikami oraz kolonizację;

- mimo odzyskania niepodległości jest wciąż nękana politycznym brakiem stabilizacji;

- dzieli się na „Afrykę Czarną” i Afrykę Północną, przy czym ta druga w sensie historycznym, kulturowym i politycznym jest bardziej związana z regionem Morza Śródziemnego i Bliskim Wschodem niż resztą kontynentu;

- nazwa Afryka pochodzi od określenia dawnej rzymskiej prowincji.

Niewątpliwie, powyższy obraz trudno zaliczyć do pozytywnych, szczególnie w świetle podawanych przez encyklopedię haseł dotyczących innych kontynentów, gdzie o problemach we wstępnej części hasła najczęściej nie wspomina się w ogóle albo wyraża się w znacznie delikatniejszy sposób i równoważy obserwacjami dotyczącymi natury czy kulturowego zróżnicowania ${ }^{3}$. Czy mamy tu do czynienia ze stereotypem, czy obiektywną wiedzą? Wydaje się, że nie da się na to pytanie odpowiedzieć jednoznacznie - z jednej strony Afryka niewątpliwie jest kontynentem, który od wieków musi stawiać czoło wielu wyzwaniom, z drugiej strony tak jednostronne jej ukazanie we wstępnej części hasła jest decyzją samych autorów. W świetle powyższych obserwacji tym bardziej pożądanym wydaje się zbadanie, jaki obraz Afryki kryje się w samym języku duńskim.

\subsection{Złożenia, derywaty i wyrażenia bliskoznaczne}

Analiza obecnych w DDO złożeń, derywatów i związanych z nimi znaczeniowo wyrażeń raczej nie przybliży nas znacznie ku osiągnięciu tego celu,

\footnotetext{
3 Por. 'Azja to kontynent kontrastów: naturę, ludność i sytuację ekonomiczną cechuje znaczne zróżnicowanie. W Azji znaleźć można prawie wszystkie formy kultury, od zbieractwa i łowiectwa po najbardziej nowoczesne kultury przemysłowe. Także forma organizacji społeczeństw i strategie rozwoju są różne.' (Den Store Danske: https://denstoredanske.lex.dk/Asien_-_verdensdel, dostęp: 2 XII 2021) oraz 'Przyroda Ameryki Południowej obejmuje znaczne kontrasty, od lasów tropikalnych i subtropikalnych pustyni na północy po obszary zlodowaciałe na południu. Jako całość Ameryka Południowa jest słabo zaludniona i charakteryzuje się ekonomicznymi oraz społecznymi nierównościami, zarówno wewnętrznie jak i porównując wybrane państwa. Cechą wspólną wszystkich państw jest etniczna i kulturowa różnorodność oraz rola, jaką odgrywa w nich kościół katolicki' (Den Store Danske: https://denstoredanske.lex.dk/Sydamerika, dostęp: 2 XII 2021).
} 
ponieważ słownik nie dostarcza nam na tym obszarze wystarczających informacji. Przymiotnik afrikansk tłumaczony jest jako 'z Afryki, dotyczący Afryki i charakterystyczny dla Afryki i Afrykańczyków', a odnoszące się do niego wyrażenia bliskoznaczne stanowią albo hiponimy pojęcia (np. marokansk 'marokański', libysk 'libijski', czy nordafrikansk 'północnoafrykański'), albo wyrazy powiązane z kolokacją afrikansk dans 'taniec afrykański', takie jak electric boogie 'electro boogie', sportsdans 'taniec sportowy', jazzballet 'taniec jazzowy' i zumba 'zumba'. Nieco więcej informacji niosą ze sobą definicje wymienionych przez słownik rzeczowników, w szczególności afrikaner, który tłumaczony jest jako 'mieszkaniec afrykańskiego kraju' oraz 'osoba należąca do grupy ludzi, która pierwotnie pochodzi z Afryki i charakteryzuje się, między innymi, czarną skórą oraz czarnymi, kręconymi włosami'. Co ważne, słownik podaje dla tego wyrazu dwa synonimy - sort 'czarny' oraz pejoratywne neger 'murzyn' wskazując tym samym, że wartościowanie w języku osób określanych tym przymiotnikiem potrafi być negatywne i że w duńskim języku wciąż utrwalona jest opozycja CZARNY - BIAŁY. Oprócz tego, podobnie jak w przypadku przymiotnika afrikansk 'afrykański', DDB podaje dla wyrazu afrikaner grupę wyrazów bliskoznacznych będących jego hiponimami, to znaczy marokansk 'marokańczyk', zimbabwer 'mieszkaniec Zimbabwe' etc. Wspomniana wyżej opozycja CZARNY - BIAŁY odzwierciedla się również w rzeczownikach afrikaaner i afrikaans, które zgodnie z definicjami zamieszczonymi w DDO odnoszą się do 'białych mieszkańców Republiki Południowej Afryki, których korzenie sięgają czasów kolonialnych, i ich języka'. Jak widać, afrykańska rzeczywistość jest nieco bardziej skomplikowana, z mieszkańcami Afryki Północnej z jednej strony i białymi mieszkańcami RPA z drugiej, ale przekonanie, że w Afryce mieszkają ludzie o czarnym kolorze skóry jest niewątpliwie częścią językowego obrazu tego kontynentu4 ${ }^{4}$. Drugim elementem językowo spetryfikowanej wiedzy o Afryce, którą odnaleźć możemy na tym etapie analizy, jest świadomość panujących $\mathrm{w}$ różnych częściach kontynentu trudnych warunków

\footnotetext{
${ }^{4}$ Jeśli chodzi o wartościowanie tego elementu językowego stereotypu Afryki, zdecydowałem się w niniejszym artykule nie przytaczać powiedzeń czy dowcipów o podłożu rasistowskim, jednak skalę problemu w dużym stopniu może oddać słowo hyggeracisme, które niedawno zostało wprowadzone do duńskiego słownika, i które oznacza w przybliżeniu 'rasizm dla zabawy'. Zjawisko opisywane przez ów wyraz dotyka oczywiście nie tylko Afrykanów i osób wywodzących swe korzenie z Afryki, ale wymieniona powyżej opozycja CZARNY - BIAŁY stanowi zdecydowanie jeden z najczęściej wykorzystywanych w tym kontekście motywów. Warto w tym miejscu dodać, że również inne elementy językowego obrazu Afryki, przede wszystkim sytuacja materialna jej mieszkańców, potrafią stanowić podstawę do tego rodzaju dowcipów.
} 
materialnych i związana z tym chęć pomocy, które odzwierciedlone są w złożeniu Afrikaindsamling 'zbiórka na Afrykę'. Na koniec, ciekawie jest zauważyć, że słownik DDO zarejestrował również czasownik afrikanisere 'afrykanizować' oraz derywowany od niego rzeczownik afrikanisering 'afrykanizacja', które oddają postawę mieszkańców Afryki wyrosłą ze sprzeciwu wobec trwającego od wieków narzucania Afryce zachodnich wartości i postulującą powrót do tradycji charakterystycznych dla kontynentu i jego mieszkańców sprzed czasów kolonialnych.

\subsection{Korpus}

Powyższe dwa podrozdziały zasygnalizowały istnienie pewnego utartego sposobu postrzegania Afryki, a także pozwoliły wyłonić jego pierwsze elementy - najmocniej zdaje się odciskać w języku świadomość tego, że kontynent ten nękany jest różnego rodzaju problemami i że zamieszkują go ludzie o czarnym kolorze skóry. Jednak wydaje się, że analiza danych słownikowych to zbyt mało, by zarysować pełen obraz konotacji związanych ze słowami takimi, jak Afrika 'Afryka' czy afrikaner 'Afrykanin'. Wobec tego koniecznym wydaje się zbadanie najbardziej utrwalonych połączeń wyrazowych zawierających owe wyrazy. Główny punkt ciężkości niniejszego badania spoczywał na dwóch zdecydowanie najbardziej produktywnych wzorach połączeń: rzeczownik + i Afrika 'w Afryce' oraz afrikansk 'afrykański' + rzeczownik. Warto zaznaczyć, że zaprezentowana poniżej analiza danych korpusowych, oprócz badania najbardziej utrwalonych połączeń wyrazowych, obejmowała również szczegółowy wgląd w pojedyncze konteksty, co pozwalało niekiedy na uchwycenie pewnych niuansów, które w innym wypadku mogłyby zostać utracone.

\subsubsection{Rzeczownik + i Afrika 'w Afryce'}

Już pierwszy $\mathrm{z}$ analizowanych wzorów konkurencji pozwala na znaczne rozwinięcie stereotypowego obrazu Afryki zarysowanego w poprzednich podrozdziałach niniejszego artykułu. Najczęściej występującą w korpusie frazą składającą się z rzeczownika oraz wyrażenia przyimkowego i Afrika 'w Afryce' jest land i Afrika 'kraj w Afryce'. Nieco głębszy wgląd w konteksty, w których owo połączenie wyrazowe występuje, pozwala zrozumieć, że nie jest ono neutralne znaczeniowo i że wiążą się z nim pewne konotacje, przede wszystkim bieda (fattigste / allerfattigste / ludfattige lande i Afrika 'biedne / najbiedniejsze / biedne jak mysz kościelna państwa w Afryce') 
oraz niski poziom rozwoju (underudvikle lande i Afrika 'słabo rozwinięte państwa w Afryce', lande i det sydelige Afrika, som lider under sult og underudvikling 'państwa w południowej Afryce, które cierpią z powodu głodu i słabego rozwoju') - ta druga cecha jest również utrwalona w specjalnie utworzonym złożeniu uland 'zacofany kraj / kraj rozwijający się’5, które również chętnie konotuje z wyrażeniem przyimkowym i Afrika 'w Afryce'. Wart wspomnienia jest również fakt, że w aż 55 z 62 (ok. 89\%) relewantnych kontekstach omawiane przez nas połączenie wyrazowe występuje w liczbie mnogiej, co mogłoby wskazywać, że Afryka najczęściej jest w Danii traktowana zbiorczo, jako zlepek podobnych do siebie państw definiowanych przez pryzmat takich samych problemów. Niewątpliwie rolę odgrywa jednak tutaj również słaba znajomość Afryki, naturalnie związana z jej odległym dla Duńczyków położeniem geograficznym - w przypadku ekwiwalentnej frazy dotyczącej państw europejskich liczba mnoga występuje w korpusie stosukowo rzadziej (164 z 234 kontekstów, czyli ok. 70\%).

Kolejnym z najczęściej występujących połączeń wyrazowych z wyrażeniem przyimkowym i Afrika 'w Afryce' jest problemer i Afrika 'problemy w Afryce', które sugeruje, że Afryka często kojarzy się użytkownikom języka duńskiego z problemami. Ta wskazówka okazuje się trafna w świetle dalszej analizy - prawie wszystkie występujące w korpusie wyrażenia i konteksty, w których się one pojawiają, sprowadzają się do tego właśnie mianownika. Silnie reprezentowana w zebranym materiale jest wspomniana już wcześniej bieda (fattigdom i Afrika 'bieda w Afryce'), która odciska piętno na mieszkańcach tego kontynentu borykających się z głodem (sult i Afrika) oraz ogólną beznadzieją (katastrofer / elendgihed / nød og opstand / økonomisk opløsning i Afrika 'katastrofy / beznadzieja / bieda i niepokoje społeczne / ekonomiczny rozkład w Afryce', mennesker i Afrika lever i elendige forhold 'ludzie w Afryce żyją w beznadziejnych warunkach'). Często owe problemy wspominane są w kontekście dzieci, które są szczególnie narażone na głód i choroby, i które wzbudzają największe współczucie społeczności międzynarodowej (fattige børn i Afrika 'biedne dzieci w Afryce', at redde endnu et barn i Afrika 'uratować jeszcze jedno dziecko z Afryki'). Inną przyczyną afrykańskich problemów, które przeniknęły do świadomości użytkowników języka duńskiego, są liczne wojny (konflikter / stridigheder / krige / massakrerne i Afrika

\footnotetext{
${ }^{5}$ Jak informuje słownik DDO, złożenie uland zostało oryginalnie utworzone od słów underudviklet 'słabo rozwinięty' oraz land 'kraj', jednak z czasem zaczęto je stosować jako skrót od udviklings land, czyli 'kraj rozwijający się'.
} 
'konflikty / niesnaski / wojny / masakry w Afryce'), które sprawiają, że życie w niektórych jej rejonach jest właściwie niemożliwe (urohærgede, krigshærgede, livstruende områder i Afrika 'niespokojne / nękane wojnami / niebezpieczne dla życia obszary w Afryce'). Niewątpliwie ma to związek z niestabilną sytuacją polityczną w wielu krajach, które rządzone są przez dyktatorów (diktator / diktaturer i Afrika 'dyktator / dyktatury w Afryce'). To wszystko sprawia, że Afryka boryka się z ogromną liczbą uchodźców i ludzi przepędzonych (flygtninge, flygtningelejre, flygtningeproblemer i Afrika 'uchodźcy / obozy dla uchodźców / problemy z uchodźcami w Afryce’), którzy próbują szukać godniejszych warunków życia na innych obszarach kontynentu lub nawet poza Afryką.

Oprócz wymienionych powyżej sądów dotyczących tego, jaka Afryka jest, duński obraz świata odzwierciedlony w analizowanych przez nas kolokacjach zawiera w sobie również pewien silnie utrwalony sposób postrzegania relacji między światem zachodnim a Afryką. W tym kontekście wyraźnie odznaczają się trzy grupy wyrażeń. W świetle pierwszej z nich, Afryka pojmowana jest jako strefa wpływów państw zachodnich (indflydelse / interessesvære i Afrika 'wpływy / strefa wpływów w Afryce'), w której dba się o własne interesy (egne / franske interesser i Afrika 'własne / francuskie interesy w Afryce') i ma swych sprzymierzeńców (støtter / faste støtter i Afrika 'sojusznicy / stali sojusznicy w Afryce'), niejednokrotnie utrzymujących się przy władzy jedynie dzięki interwencji zachodnich sojuszników, co widać wyraźnie w poniższych dwóch przykładach:

[1] Men for at beskytte vitale franske interesser i Afrika, har de ofte endt med at støtte sig til korrupte diktatorer som Mobutu. ['Lecz by chronić kluczowe francuskie interesy w Afryce często opierali się na skorumpowanych dyktatorach, takich jak Mobutu.'] (Korpus.dk: Afrika - En klods om Frankrigs ben, dostęp: 2 XII 2021).

[2] Én af Frankrigs politiske stråmænd i Afrika, den central-afrikanske præsident Jean BedelBokassa, var i sin tid som sergent i den franske kolonihær blevet en stor beundrer af Napoleon. ['Jedna $\mathrm{z}$ francuskich politycznych marionetek w Afryce, środkowoafrykański prezydent Jean Bedel Bokassa, w czasach gdy służył jako sierżant we francuskim wojsku kolonialnym stał się wielkim fanem Napoleona.'] (Korpus.dk: Afrika - En klods om Frankrigs ben, dostęp: 2 XII 2021). 
W świetle licznie występujących wyrażeń koloni / kolonier i Afrika 'kolonia/kolonie w Afryce' widać natomiast wyraźnie, że państwa afrykańskie są w duńskim obrazie świata wciąż częściowo pojmowane przez pryzmat ich dawnego statusu jako kolonii. Z jednej strony należy zaznaczyć, że, tak jak w przypadku zacytowanych powyżej przykładów dotyczących afrykańskich dyktatorów służących obcym interesom, nie musi to z reguły oznaczać akceptacji opisywanego zjawiska. Z drugiej strony jednak nader rzadko wiąże się też przeszłość kolonialną Afryki z jej współczesnymi problemami najczęściej wyrażenie koloni (er) i Afrika służy po prostu konstatacji faktu historycznego. W tym kontekście warto zwrócić uwagę na drugą grupę wyrażeń związaną z działaniami militarnymi w Afryce, których zasadność podważa się bardzo rzadko. W tym przypadku pomaga sam język, który wojny toczone z udziałem państw europejskich i USA pozwala oddać w postaci OPERACJI (operationer i Afrika 'operacje w Afryce'), INTERWENCJI (intervention i Afrika 'interwencje w Afryce'), czy nawet ZAANGAŻoWANIA (militær engagement i Afrika 'militarne zaangażowanie w Afryce') i zoBowiązANia (mil. forpligtelser i Afrika 'militarne zobowiązania w Afryce'). W podobny sposób zwykło się przedstawiać próbę przekonwertowania afrykańskich społeczeństw na zaimportowaną z Zachodu religię, co odzwierciedla się w wyrażeniu missionær i Afrika 'misjonarz w Afryce', przedstawiającym owo zjawisko jako MISJĘ czy nawet pewne POWOŁANIE. Powyższy obraz relacji Zachód Afryka neutralizuje nieco trzecia grupa wyrażeń skupiająca się wokół pomocy, która niesiona jest potrzebującym mieszkańcom Afryki (nødhjælp / hjælparbejde / (heroiske) sygplejersker / læge / projekter i Afrika 'pomoc humanitarna / praca humanitarna / (bohaterskie) pielęgniarki / lekarz / projekty w Afryce, etablere en skole i Afrika 'zbudować szkołę w Afryce'). Warto w tym kontekście jednak nadmienić, że istnieją w Afryce silne kręgi postulujące zerwanie relacji zależności od świata zachodniego, w których wartościowanie pomocy napływającej z państw zachodnich jest co najmniej niejednoznaczne. Inną prezentowaną niejednokrotnie postawą jest postrzeganie tej pomocy jako oczywistego zadośćuczynienia za szkody czynione Afryce w czasie kolonialnym i w ramach współczesnego systemu neokolonialnego.

Ostatnia grupa kolokacji złożonych z rzeczownika i wyrażenia przyimkowego i Afrika, która wyraźnie odznacza się w korpusie, odwołuje się do Afryki rozumianej jako środowisko naturalne i dzika przyroda, np. flod / dyr / fuglene / regnskoven / savannen i Afrika 'rzeka / zwierzęta / ptaki / las deszczowy / sawanna w Afryce'. Z tego powodu Afryka jest często postrzegana 
jako cel wakacji zachodniego turysty, który chce doświadczyć jej egzotyki (besøg / rejser /turister / ferie / vinterferie / ferieopholdssted / en tur / fotosafari i Afrika 'podróż / turyści / wakacje / wakacje zimowe / miejsce na wakacje / wycieczka / foto safari w Afryce'). Jeśli spojrzymy na zebrany materiał globalnie, najbardziej uderza fakt, że oprócz zaobserwowanej powyżej świadomości różnorodności naturalnej i kilku pojedynczych wyrażeń, takich jak VM i Afrika 'mistrzostwa świata w Afryce', årets spiller i Afrika 'gracz roku w Afryce' czy maler i Afrika 'malarz w Afryce', niemal wszystkie konteksty odnoszą się do zjawisk jednoznacznie negatywnych. Warto więc sprawdzić, czy podobnie rzecz ma się w przypadku przymiotnika afrikansk 'afrykański'.

\subsection{2. afrikansk + rzeczownik}

Niewątpliwie zarysowany powyżej obraz Afryki powtarza się w dużej mierze podczas analizy połączeń przymiotnika afrikansk 'afrykański' z rzeczownikami. W świetle najczęściej występującej frazy afrikanske lande 'kraje afrykańskie’ jeszcze wyraźniej ujawnia się stereotyp afrykańskiego państwa, składający się między innymi z elementów takich jak bieda (fattige / fattigste afrikanske lande 'biedne / najbiedniejsze państwa afrykańskie') i wojny (anmodede øvrige afrikanske lande om militær hjælp 'poprosili inne afrykańskie kraje o pomoc militarną', krige og elendighed i nogle afrikanske lande 'wojny i beznadzieja w niektórych państwach afrykańskich'). Tak rozumiane stereotypowe państwo afrykańskie może być postrzegane jako problem dla reszty świata, szczególnie dla świata zachodniego:

[3] Danmarks udviklingspolitik, der i årevis har arbejdet på to fronter, når det gælder hjælp til ulandene. På den ene side fungerer især de afrikanske lande så dårligt, at direkte bistand er eneste mulighed for nødhjælp, men samtidig forsøger Danmark via hjælpeprogrammer at uddanne landene til at liberalisere deres samhandel og rive de høje toldmure ned. Duńska polityka rozwojowa przez lata była prowadzona na dwóch frontach, jeśli chodzi o pomoc dla krajów słabo rozwiniętych. ['Z jednej strony przede wszystkim afrykańskie państwa funkcjonują tak źle, że bezpośrednia pomoc finansowa jest jedyną opcją w kontekście pomocy humanitarnej, ale jednocześnie Dania próbuje również pomagać słabo rozwiniętym krajom poprzez programy mające na celu liberalizację wspólnego handlu i obniżeniu ceł.'] (Korpus.dk: Folkesundhed: Detglobalehelbredskranter, dostęp: 2 XII 2021).

Z innych fraz występujących w korpusie możemy wywnioskować, że rozumienie Afryki w kategorii problemu czy zagrożenia (den afrikanske trus- 
sel 'afrykańskie zagrożenie') związane jest przede wszystkim z wizją afrykańskich imigrantów, którzy z wyżej wymienionych powodów próbują szukać szczęścia na zachodzie (afrikanske flygtninge / indvandrere / asylansøgere / tilflyttere 'afrykańscy uchodźcy / imigranci / występujący o azyl /przybysze') i to właśnie temu w dużej mierze zapobiegać ma pomoc rozwojowa przekazywana corocznie na rzecz państw w Afryce. Z drugiej strony, jeśli afrykańskie państwa funkcjonują dobrze, mogą być one postrzegane jako atrakcyjny obszar dla zachodniego inwestora, co widać w poniższym cytacie, w którym potwierdza się również eksplicytnie istnienie tendencji do ukazywania Afryki poprzez pryzmat wojen i dramatycznych warunków bytowych:

[4] Krige og elendighed i nogle afrikanske lande har præget nyhedsreportager fra Afrika og haft tendens til at overskygge, at i de fleste af Afrikas mere end 50 lande er der $i$ de senere år kommet mere ordnede forhold og attraktive betingelser for udenlandske investorer. ['Wojny i beznadzieja w niektórych krajach afrykańskich stanowią większość wiadomości dotyczących Afryki i rzucają cień na fakt, że w większości krajów Afryki w ostatnich latach pojawiły się przyzwoite warunki i atrakcyjne możliwości dla zagranicznych inwestorów.'] (Korpus.dk: FN: Profittenligger i Afrika, dostęp: 2 XII 2021).

W świetle innych fraz zebranych w tej części analizy odkryć można również i pozostałe części stereotypu Afryki, które wyszczególnione zostały już w podrozdziale 2.1. Przede wszystkim brak demokracji (afrikanske regimer / diktatorer / diktaturstater 'afrykańskie reżimy / dyktatorzy / dyktatury') oraz krwawe wojny, niejednokrotnie prowadzone na tle etnicznym (afrikanske konflikter / oprørskrigere / dræberier / soldater 'afrykańskie konflikty / bojownicy / mordowanie / żołnierze’), które odciskają swoje piętno na całej ludności, a w szczególności na dzieciach (afrikanske befolkninger / børn 'afrykańska ludność / afrykańskie dzieci'). W pojedynczo występujących frazach, takich jak afrikanske negre 'afrykańscy murzyni' i afrikanske træk 'afrykańskie rysy / cechy', widać natomiast znowu, że typowy Afrykanin postrzegany jest częściowo przez pryzmat swojego koloru skóry i wyglądu. Widok osoby z afrykańskimi korzeniami nie jest co prawda współcześnie w Danii niczym nadzwyczajnym, jako że przez lata kraj ten przyjmował uchodźców i imigrantów z różnych stron Afryki (afrikansk baggrund /afstaming 'afrykańskie korzenie / pochodzenie', afrikanske efterkommere 'osoby mieszkające w Danii z afrykańskimi korzeniami’), jednak takie osoby są 
wciąż często przedstawiane jako problem, szczególnie przez silny w Danii front nacjonalistyczno-antyimigrancki.

Postrzeganie Afryki przez pryzmat jej kłopotów jest widoczne również, jeśli przyjrzymy się kontekstom zawierającym frazę det afrikanske kontinent 'afrykański kontynent', np. mange kriser på det afrikanske kontinent 'wiele kryzysów na kontynencie afrykańskim' czy u landsstater på det afrikanske kontinent 'biedne kraje na kontynencie afrykańskim'. Po raz kolejny możemy także dostrzec, że Afryka jest stosunkowo często oceniana przez pryzmat działań militarnych państw zachodnich oraz braku demokracji:

[5] Soyinka indrømmer, at det er gået tilbage for demokratiet mange steder på det afrikanske kontinent, navnlig i Vestafrika. ['Soyinka przyznaje, że wiele miejsc w Afryce poczyniło krok wstecz, jeśli chodzi o demokrację, przede wszystkim państwa w Afryce Zachodniej.'] (Korpus.dk: Terror mod journalister, dostęp: 2 XII 2021).

[6] De to missioner har fået USA og andre vestlige nationer til på forhånd at afvise udstationeringen af tropper på det afrikanske kontinent. ['Te dwie misje sprawiły, że USA i inne zachodnie państwa z góry odmówiły rozmieszczenia swych wojsk na afrykańskim kontynencie.'] (Korpus.dk: Sierra Leone: USA ude af Afrika, dostęp: 2 XII 2021).

Niemniej jednak należy zauważyć, że obraz Afryki odzwierciedlający się we frazach zawierających przymiotnik afrikansk 'afrykański' jest bardziej zróżnicowany i pojawia się w nim między innymi świadomość tego, że Afryka ma swoją kulturę manifestującą się w różnych dziedzinach sztuki (afrikanske kunstnere / håndværkere 'afrykańscy artyści / rzemieślnicy'), np. literaturze (afrikanske forfattere 'afrykańscy pisarze'), filmie (afrikanske film 'afrykańskie filmy') i, być może przede wszystkim, muzyce (afrikanske trommer / rytmer / musiktraditioner 'afrykńskie bębny / rytmy / tradycje muzyczne) ${ }^{6}$. Użytkownicy języka duńskiego zdają się ponadto wiedzieć, że Afryka wydała na świat wielu utalentowanych sportowców (afrikanske spillere 'afrykańscy zawodnicy'), w szczególności biegaczy (afrikanske løbere 'afrykańscy biegacze’). Niewątpliwie jednak najmocniej utrwalonym pozytywnym elementem

\footnotetext{
${ }^{6}$ Choć wszystkie te pojedyncze frazy przyćmione zostały przez wyrażenie afrikansk maske / afrikansk e masker 'afrykańska maska / afrykańskie maski', co autorowi niniejszego artykułu wydaje się trudne do jednoznacznego zinterpretowania. Intuicyjnym tłumaczeniem byłaby fascynacja pierwotnością i egzotycznym z zachodniej perspektywy charakterem niektórych przynajmniej ludów afrykańskich, znajdująca odzwierciedlenie w chęci kolekcjonowania tego rodzaju przedmiotów.
} 
obrazu Afryki w języku duńskim jest jej przyroda, postrzegana przez pryzmat obszarów takich jak sawanna (afrikansk savanne 'afrykańska sawanna') czy busz (afrikansk bush 'afrykański busz') oraz dzikich i w większości egzotycznych dla Duńczyków zwierząt (afrikanske dyr / ørne / fisk / elefanter / næsehorn /pindsvin / aber / slanger 'afrykański(e) zwierzęta / orzeł / ryby / słonie / nosorożce / jeże / małpy / węże’).

\subsubsection{Inne połączenia wyrazowe}

Jak wspomniane zostało we wstępie do niniejszego rozdziału, częstotliwość występowania innych kombinacji z wyrazami Afrika oraz afrikansk nie pozwala na sformułowanie wielu konkluzji dotyczących stereotypu Afryki funkcjonującego w języku duńskim. Jeśli chodzi o związki werbonominalne, wyraz Afrika najczęściej współwystępuje z czasownikami modalnymi w formie czynnej takimi jak har 'ma' bądź er 'jest'. Pojedynczo występujące kolokacje z innymi czasownikami nie wnoszą wiele ponad to, co powiedziane zostało w poprzednich dwóch podrozdziałach. W kontekście wyrażenia Afrika bløder 'Afryka krwawi' ciekawie jest zauważyć, że Afryka w języku duńskim może być personifikowana, jednak w korpusie nie odnajdujemy metafory, która często używana jest przez samych Afrykanów, czyli AFRYKA TO MATKA. W wyrażeniach takich jak hjælpe Afrika 'pomagać Afryce', delte / opdelte Afrika 'podzielili Afrykę (na części)' oraz lade Afrika bløde / slås 'dać Afryce się wykrwawić / bić między sobą’ widzimy natomiast namiastkę dylematu przed jakim staje świat zachodni, którego wieloletnia ingerencja w sprawy Afryki jest głównym czynnikiem jej współczesnych problemów, i który współcześnie czuje się z jednej strony zobowiązany do pomocy Afryce, a z drugiej często świadomie odwraca wzrok od wyzwań, z którymi na co dzień muszą się konfrontować afrykańskie państwa. Z kolei w najczęściej występujących połączeniach z wyrazem afrikaner 'Afrykanin' odciskają się zarysowane już wcześniej główne elementy mieszkańca Afryki - przede wszystkim czarna skóra (sort afrikaner / sorte afrikanere 'czarny Afrykanin / czarni Afrykanie') oraz bieda, w której żyje (fattige/ sultende / dødsultende afrikanere 'biedni / głodni / umierający z głodu Afrykanie’), choć pojedyncze wyrażenia niosą ze sobą niekiedy również pozytywne cechy, np. talentfuld / dygtig afrikaner 'utalentowany, zdolny Afrykanin'. 


\section{Konkluzje}

W świetle powyższej analizy wyróżnione zostały najbardziej utrwalone elementy obrazu Afryki funkcjonującego w języku duńskim, co z kolei pozwala na skonstruowanie definicji kognitywnej pojęcia (Bartmiński 1988). W jej świetle Afryka to:

[POŁOŻENIE GEOGRAFICZNE] Duży, odległy Europie kontynent.

[WYMIAR POLITYCZNY] na którym jest wiele podobnych do siebie państw.

Te państwa często toczą ze sobą wojny.

Często wybuchają w nich także wojny domowe.

Nie ma w nich demokracji.

I rządzone są często przez dyktatorów.

[WARUNKI BYTOWE] Te państwa są bardzo biedne

i bardzo słabo rozwinięte

Często panuje w nich głód i śmiertelne choroby,

które dotykają szczególnie dzieci.

[ROLA ŚWIATA ZACHODNIEGO] Europa próbuje tym państwom pomagać,

zarówno ekonomicznie jak i militarnie,

ale przez wojny i brak sprawnego systemu rządzenia ta pomoc

jest często marnowana.

[STEREOTYP AFRYKANINA] W tych państwach żyją ludzie o czarnym

kolorze skóry, którzy bardzo cierpią z powodu biedy i wojen,

i którzy z tego powodu bardzo chcieliby się dostać do Europy.

[ROLA ŚWIATA ZACHODNIEGO] Należy im współczuć i pomagać,

ale niekoniecznie przez przyjmowanie ich u siebie ${ }^{7}$.

[PRZYRODA] W Afryce jest także dzika, egzotyczna przyroda,

którą warto zobaczyć i przeżyć.

[kultura] Afryka ma także swoją, egzotyczną kulturę.

Jakie wnioski możemy wyciągnąć z powyższej analizy? Odwołując się do koncepcji znaczenia zarysowanej przez Hilarego Putnama (Putnam 2013: 141-150), naturalną rzeczą jest, że za słowami języka naturalnego kryją się przede wszystkim stereotypy (w odróżnieniu od ekstensji i związanej z nią wiedzy eksperckiej), czyli innymi słowy uproszczone modele świata, które pozwalają użytkownikom języka radzić sobie z tym ogromem informacji, które napływają do nich w każdej chwili ze świata, a także dzielić się swymi

\footnotetext{
7 Druga część frazy ma za cel oddać zróżnicowanie w poglądach Duńczyków na tę kwestię. Wydaje się jednak, że w ostatnich latach front antyimigrancki zyskał w Danii na sile.
} 
spostrzeżeniami na temat otaczającej ich rzeczywistości w konwencjonalny sposób. W niektórych przypadkach takie uproszczenia mogą być jednak bardzo krzywdzące i szkodliwe - szczególnie gdy dotyczą one innych ludzi i tworzonych przez nie społeczności. Obraz Afryki wyłaniający się z przebadanego w niniejszym artykule materiału językowego jest uderzająco negatywny. Dominują w nim wojny, głód i ogólna beznadzieja, podczas gdy świadomość zróżnicowania kulturowego tego kontynentu wydaje się być bardzo niska. Nie wydaje się też, by przeciętny Duńczyk wiązał współczesną sytuację w Afryce z kolonializmem i wiekami drenowania jej z zasobów naturalnych i ludzkich - Afryka jest po prostu problemem. Takie postrzeganie Afryki nie jest jedynie niesprawiedliwe, ale może mieć daleko idące konsekwencje. Jeśli w języku duńskim punktem wyjścia do rozważań na temat Afryki jest powyższy stereotyp, istnieje duże ryzyko, że będzie on predeterminował postrzeganie pojedynczych zagadnień, takich jak imigracja, kolonializm (współcześnie neokolonializm), czy nawet usprawiedliwianie inwazji militarnych, a także zachęcał do zamknięcia się w kręgu europocentrycznego samozadowolenia i protekcjonalnego postrzegania innych kultur.

Pozostając w koncepcji znaczenia Putnama, wydaje się, że przed ważnym wyzwaniem stoją w tej kwestii „eksperci”, czyli ludzie, którzy powinni mieć znacznie bardziej zniuansowaną wiedzę na temat Afryki i dążyć do rozpowszechnienia tej wiedzy w społeczeństwie. W tym kontekście wydaje się, że powyższe badanie nieodzownie musi zostać poparte badaniem duńskiego dyskursu, aby ustalić, czy dziennikarze, którzy z definicji w roli takich ekspertów występują, również nie popadają w krąg tych samych, prostych schematów myślowych.

\section{Literatura}

Bartmiński J. (1988): Definicja kognitywna jako narzędzie opisu konotacji, w: Konotacja, (red.) J. Bartmiński, Lublin.

Bartmiński J. (2007): Stereotypy mieszkają w języku: studia etnolingwistyczne, Lublin.

Bartmiński J. (2012): Jezykowe podstawy obrazu świata, Lublin.

Putnam H. (2013): Wiele twarzy realizmu i inne eseje, Warszawa.

Underhill J.W. (2009): Humboldt, Worldview and Language, Edynburg. 


\section{Słowniki i korpusy}

Den Danske Begrebsordbog (DDB): NimbSanni, Trap-Jensen Lars, Lorentzen Henrik, TheilgaardLiisa, Troelsgaard Thomas, 2015, Den Danske Begrebsordbog, Kopenhaga.

Den Store Danske: https://denstoredanske.lex.dk/.

Den Danske Ordbog (DDO): https://ordnet.dk/ddo.

KorpusDK: https://ordnet.dk/korpusdk.

\section{Africa in the eyes of the Western World - The Linguistic Stereotype of Africa and Africans in Danish}

The present paper aims to investigate the way in which Africa is perceived by Danish speakers in light of the most petrified linguistic expressions and corpus data. As it turns out, the received picture is largely negative, with elements such as POVERTY, DISEASES, LACK OF DEMOCRACY, WARS and ETHNIC CLASHES in its foreground. Moreover, in the majority of the analyzed contexts Africa is presented as a cluster of similar countries facing the same challenges, with little room for the awareness of the great cultural diversity that flourishes on the continent. In this context, it is also worth adding that the analyzed collocations also convey a closely related stereotype of the inhabitants of Africa, regarded primarily through the prism of the color of their skin and the suffering they must endure on their continent. It is no surprise, then, that Africa and African people are quite often perceived as a problem for the western world, especially because of the highly-feared waves of immigrants and asylum seekers that occur regularly on the continent. On the other hand, at least in the light of the analyzed material, there seems to be no to little realization of the fact that many of the problems of Africa stem from the ages of draining its human and natural resources by the colonial powers. As argued by the author of the present article, such a picture of Africa is not only unfair but may have other consequences as well, possibly predetermining how Danes willview single issues such as immigration or military invasions, and letting them fall into the spiral of eurocentric and patronizing understanding of the world.

Keywords: stereotype, Africa, African people, Danish language, eurocentrism, neo-colonialism, Danish worldview

Słowa kluczowe: stereotyp, Afryka, Afrykanin, język dunski, europocentryzm, neokolonializm, duński obraz świata 